\title{
USE OF METABOLIC PROFILES AND BODY CONDITION SCORING FOR THE ASSESSMENT OF ENERGY STATUS OF DAIRY COWS
}

\author{
R. Prodanović ${ }^{1}$, Ž. Sladojević ${ }^{2}$, D. Kirovski ${ }^{3}$, I. Vujanac ${ }^{3}$, V. Ivetić ${ }^{1}$, B. Savić ${ }^{1}$, \\ B. Kureljušić ${ }^{1}$, M. Stevančević ${ }^{4}$
}

${ }^{1}$ Scientific Veterinary Institute of Serbia, Vojvode Toze 14, 11000, Belgrade, Republic of Serbia.
${ }^{2}$ Veterinary Station ,Veterina system Sladojević“, Topola, Republic of Srpska.
${ }^{3}$ Faculty of Veterinary Medicine, Bulevar oslobođenja 18, 11000, Belgrade, Republic of Serbia.
${ }^{4}$ Faculty of Agriculture, Department of Veterinary Medicine, Trg Dositeja Obradovića 8, 21000, Novi
Sad, Republic of Serbia.
Corresponding author: radisaprodanovic@yahoo.com
Original scientific paper

\begin{abstract}
The aim of this study was to assess the significance of body condition scoring and metabolic profile test for estimation of energy status of healthy high-yielding dairy cows. Twenty one healthy cows (primiparous and secundiparous) were divided into three groups: dry cows, early puerperal cows and early lactating cows. Cow's energy status was estimated by the analysis of blood samples for beta-hydroxybutirate (BHBA) and glucose. Additionally, urea, total bilirubine and total protein were measured in blood serum samples. According to body condition scores (BCS) results dry cows were overweight (4.03 \pm 0.29 points). Immediately after calving, cows lost their weight significantly, since BCS was $2.85 \pm 0.46$ points at puerperal period and $3.12 \pm 0.33$ points at day 60 of lactation $(\mathrm{p}<0.001$ compared to dry period, respectively). Glucose concentration did not change significantly between dry and puerperal period, while BHBA increased significantly $(0.46 \pm 0.14 \mathrm{mmol} / 1$ at dry period to $1.08 \pm 0.21 \mathrm{mmol} / 1$ at puerperal period; $\mathrm{p}<0.001)$. Urea concentration did not change significantly during examined period. Total bilirubin concentration significantly increased from dry $(6.31 \pm 0.37$ $\mathrm{mmol} / \mathrm{l})$ to puerperal period $(7.63 \pm 2.52 \mathrm{mmol} / \mathrm{l} ; \mathrm{p}<0.001$ compared to dry period) and remained high until day 60 of lactation $(7.62 \pm 0.13 \mathrm{mmol} / \mathrm{l} ; \mathrm{p}<0.001 \mathrm{compared}$ to dry period). Total protein concentration decreased from dry to puerperal period $(69.59 \pm 6.14 \mathrm{~g} / 1$ to $58.87 \pm 3.29 \mathrm{~g} / \mathrm{l} ; \mathrm{p}<0.001)$. According to obtained results it can be concluded that cows were not in adequate energy status during transition period. Our results also indicate that, body condition scoring, BHBA and total bilirubin concentrations can be used as reliable indicators of cow's energy status even when there are not clinically visible health disorders.
\end{abstract}

Key words: cow, energy status, metabolic profile 


\section{Introduction}

Metabolic profile is useful tool to indicate if homeostatic mechanisms are capable to keep blood parameters within physiological range under different feeding and housing conditions (Ivanov et al., 2005). Lotthammer (1991) consider that determination of metabolic parameters, together with nutrition and health status monitoring in herd, can identify subclinical disorders and indicate on their etiology. If metabolic profile application is well planed and if it is done together with body condition scoring, estimation of housing system and feeding regime, it can be valid diagnostic tool for assessment of herd health (Reist et al., 2002; Kida, 2003).

Metabolic profile parameters are of great importance for early identification of energy metabolism disturbances in cows. Most reliable indicators of cow's energy status are beta-hydroxibutirate acid (BHBA) and glucose concentrations during dry period and bilirubineia during puerperal period (Kirovski et al., 2009). Concentrations of these parameters are in high correlation with blood non-esterified fatty acid (NEFA) concentrations and body condition scores during peripartal period (Stengärde, 2008; Prodanović et al., 2010).

Several studies have shown that over-conditioned dry cows have a greater depression of feed intake during peripartal period and deeper negative energy balance than cows with a lower body condition (Hayirli et al., 2002; Rukkwamsuk et al., 1999). High body condition scores (BCS) before calving, as well as major losses in body condition after calving have been associated with abomasal displacement, ketosis and other metabolism related diseases, decreased fertility and increased culling rates (Morrow 1976; Hayirli et al., 2002). Peripartal energy balance disturbances are considered to be major contributing factors to the dairy cows' metabolic problems in herds in Serbia (Šamanc et al., 2008; 2010).

The aim of this study was to assess the significance of body condition scoring and metabolic profile test for estimation of energy status of healthy highyielding dairy cows.

\section{Materials and methods}

Body condition scoring and metabolic profile test were conducted in a high-yielding dairy Holstein cow from commercial farm. Average daily milk production per cow was about 20 liters. All the animals included in the experiment were heifers or second calving cows. Cows were kept in free stalls systems. Dry cows were fed only by straw one day and restricted rations of TMR the next days until close-up diet which was applied 2-3 weeks before calving. Lactating cows were fed with total mixed rations. The animals were fed twice a daily. 
Total number of 21 dairy cows, divided into three groups ( $\mathrm{n}=7$ per group), were investigated. First group included dry cows (15 days before expected calving); second group included early puerperal cows (7 days after the calving); third group included early lactating cows (day 60 of lactation). Body condition scores (BCS) were obtained on $10 \%$ of total number of cows on the farm using 5point scale system recommended by Elanco Animal Health Buletin AI 8478 (Milovanović et al., 2005).

Blood samples were taken from those cows by jugular venipuncture 4 hours after the morning feeding. Concentrations of glucose and betahydroxybutyric acid (BHBA) were determined in samples of fresh blood (Precision Xceed). The concentrations of total protein, urea and total bilirubin in blood serum samples were tested. The concentrations of biochemical constituents of blood serum were determined by photometric method using a commercial test package (Bio-Medica).

Test results were analyzed using standard statistical methods to calculate the mean and standard deviation. For evaluation of significant differences between mean values was used Student's t-test.

\section{Results and discussion}

Body condition scoring results, differences between BCS mean values and concentrations of examined biochemical parameters are shown in Tables 1,2 and 3.

Table 1. Results of body condition scores (BCS)

\begin{tabular}{|c|c|c|c|}
\hline & \multicolumn{3}{|c|}{ Values of examined parameters $(\mathrm{X} \pm \mathrm{SD})$} \\
\hline & $\begin{array}{c}15 \text { days before expected } \\
\text { calving }\end{array}$ & 7 days after the calving & day 60 of lactation \\
\hline BCS (points) & $4.03 \pm 0.29$ & $2.85 \pm 0.46^{* * * a}$ & $3.12 \pm 0.33 * * *$ \\
\hline
\end{tabular}

Legend: ${ }^{* * *} \mathrm{p}<0,001$; compared to dry period

Table 2. Results of differences between BCS

\begin{tabular}{|c|c|c|c|}
\hline & \multicolumn{3}{|c|}{ Values of examined parameters (X \pm SD) } \\
\hline $\begin{array}{c}\text { Differences } \\
\text { (points) }\end{array}$ & $\begin{array}{c}\text { Dry period/ } \\
\text { puerperium }\end{array}$ & $\begin{array}{c}\text { Dry period/ } \\
\text { day } 60 \text { of lactation }\end{array}$ & $\begin{array}{c}\text { day } 60 \text { of lactation / } \\
\text { puerperium }\end{array}$ \\
\hline & $1.18 \pm 0.27$ & $0.91 \pm 0.18$ & $0.27 \pm 0.08$ \\
\hline
\end{tabular}


Table 3. Concentrations of total protein, urea, glucose, BHBA and total bilirubin

\begin{tabular}{|c|c|c|c|}
\hline & \multicolumn{3}{|c|}{ Values of examined parameters $(\mathrm{X} \pm \mathrm{SD})$} \\
\hline & $\begin{array}{c}15 \text { days before } \\
\text { expected calving }\end{array}$ & $\begin{array}{c}7 \text { days after the } \\
\text { calving }\end{array}$ & day 60 of lactation \\
\hline Total protein $(\mathrm{g} / \mathrm{l})$ & $69.59 \pm 6.14$ & $56.87 \pm 3.29^{* * * \text { aaa }}$ & $67.71 \pm 8.10$ \\
\hline Urea $(\mathrm{mmol} / \mathrm{l})$ & $7.73 \pm 2.34$ & $8.07 \pm 3.09$ & $7.41 \pm 2.03$ \\
\hline Glucose $(\mathrm{mmol} / \mathrm{l})$ & $2.81 \pm 0.27$ & $3.06 \pm 0.90$ & $3.03 \pm 0.26$ \\
\hline BHBA $(\mathrm{mmol} / \mathrm{l})$ & $0.46 \pm 0.14$ & $1.08 \pm 0.21$ & \\
\hline Bilirubin $(\mu \mathrm{mol} / \mathrm{l})$ & $6.31 \pm 0.37$ & $7.63 \pm 2.52^{* * *}$ & $7.62 \pm 0.13^{* * *}$ \\
\hline
\end{tabular}

Legend: $* \mathrm{p}<0.05 ; * * \mathrm{p}<0.01 ; * * * \mathrm{p}<0.001 ;$ compared to dry period

${ }^{a} \mathrm{p}<0.05$; ${ }^{\text {aa }} \mathrm{p}<0.01 ;{ }^{\text {aaa }} \mathrm{p}<0.001$; compared to day 60 of lactation

It can be observed on the grounds of the results presented in Table 1 that the body condition scor of cows in early puerperium and on day 60 of lactation was statistically significantly lower $(\mathrm{p}<0.001)$ in comparison with the body condition established during the dry period. The results of the body condition scoring (BCS) clearly indicate that the body condition during the dry period is not in accordance with the physiological values, so that the values obtained during the dry period are shifted to the ,right" of the physiological values. Contrary to this, during early puerperium and during the early stage of lactation they are shifted more to the „left.“ This is why the differences between the average values of the body score are most expressed between the dry period and puerperium ( $\mathrm{X}=1.18$ points) and the dry period and the early stage of lactation ( $X=0.89$ points). Data from literature indicate that this difference should not be higher than 0.5 or at least no higher than 0.7 points (Milovanović et al., 2005; Šamanc et al., 2010).

The results of investigations of parameters of the metabolic profile are in accordance with the examined data on the evaluated body score. Based on the results presented in Table 3 , it is noted that the average concentrations of total proteins during the dry period and on day 60 of lactation were significantly higher in comparison with the values obtained during early puerperium $(p<0.001)$. The values obtained for the concentrations of urea and glucose were not statistically significantly different between the examined periods. It can also be seen from Table 3 that there are digressions from physiological values in the concentrations of urea and total proteins during early puerperium, as well as in the concentration of urea during the dry period and in early lactation. The average values for urea concentrations in blood serum of all examined cow groups were significantly higher than the values presented by other authors. According to Jazbec (1990), the upper physiological value for urea concentration in blood is $6.66 \mathrm{mmol} / \mathrm{l}$. Urea concentration in cow blood during the peripartal period largely depends on the supply of the protein component in the feed ration, but it can also be a good indicator of the cow's energy supply. Namely, in the event of an energy deficiency in the ration, degradable food proteins cannot be fully utilized for the synthesis of 
bacterial protein. That is why unutilized ammonia that occurred through the deamination of liver proteins is used for urea synthesis (Marenjak et al., 2004).

It has been proven that a surplus of proteins regarding the existing requirements for certain categories of cows poses a real threat in the sense of the launching of a lipomobilization process, and even when there are no physiological reasons for that (Lotthammer, 1991). The extent of this danger to the metabolic status of the animals, and even the functional condition of the liver, can be seen in the values for the concentrations of urea and total proteins in blood of postpartal cows. These animals have been found to have the lowest values for proteinemia $(X=56.8 \pm 3.29$ $\mathrm{g} / \mathrm{l})$ and the highest concentrations of urea in blood $(\mathrm{X}=8.07 \pm 3.09 \mathrm{mmol} / \mathrm{l})$.

Observations of the individual values for blood concentrations of urea and glucose have shown that the lowest glycemia values were established in cows with the highest level of urea in blood. This finding confirms the already presented stand that the fermentation processes in the rumen are in close relation to the degree of urea synthesis and the gluconeogenesis process in the liver. Namely, it has been proven that ammonia slows down the gluconeogenesis process in the liver because the common substrate oxaloacetate is used for both glucose synthesis and aspartate synthesis, which is necessary in the process of ureogenesis (Marenjak et al., 2004). If we take into consideration that milk production is not in keeping with the genetic potentials of animals, then it is understandable why there are no more serious disruptions in the health condition and why the blood glucose concentration is within physiological limits in all examined animal categories. However, it is interesting to note the finding on day seven after calving when the average glucemia value was $3.06 \pm 0.90 \mathrm{mmol} / \mathrm{l}$, and the average BHBA concentration was higher than the physiological value $(X=1.08 \pm 0.21 \mathrm{mmol} / \mathrm{l})$. This indicates that cows during this period utilized greater quantities of body fat reserves and this is why there was a greater possibility for the ketogenesis process to become intensified (Gustafsson et al, 1995). The difference in body condition established between the dry period and early puerperium (1.18 points) most strongly indicates the validity of this stand.

It can also be observed from Table 3 that the average value of total bilirubin concentration during the dry period was significantly lower than in early puerperium and on day 60 of lactation $(\mathrm{p}<0.001)$. Of particular interest are the results for total bilirubin concentration obtained during early puerperium because in almost $30 \%$ of the examined animals the obtained values were significantly higher than the physiological value, which, according to Kaneko (1989) amounts to up to $8.55 \mu \mathrm{mol} / 1$. This finding confirms the viewpoint that in obesed cows, during the transition from a state of positive to a state of negative energy balance (the peripartal period), there is a danger of uncontrolled mobilisation of adipose tissue taking place. In certain animals, this process can in the beginning evolve into a pathological condition, whose basis always comprises a smaller or higher degree of fatty liver (Šamanc et al., 2008). There are data in literature that clearly indicate 
that even the slightest degree of fattiness of this organ results in an elevated concentration of total bilirubin in the blood of the animal (Rosenberger, 1995).

The determination of total bilirubin concentration provides significant insight into the functional state of the liver and indirectly into the energy status of the animal. Bilirubinemia values of up to $6.84 \mu \mathrm{mol} / \mathrm{l}$ can be found in cows during fasting or the period around calving, when a mild form of fatty infiltration of the liver occurs. Values over $8.55 \mu \mathrm{mol} / 1$ are considered pathological and a consequence of fatty infiltration and degeneration of liver cells. In such cases, the excretory function of this organ is weakened (Šamanc et al., 1992).

\title{
Conclusion
}

Based of results presented in this paper it can be concluded that cows at examined commercial farm were not properly prepared for lactation. Although there was no visible signs of health disorders, biochemical parametars and body condition scoring obtained in this work showed that cows sufferd from pronaunced negative energy balance during postpartal period.

\section{Acknowledgment}

This work was financed by the Ministry of Education and Science, Republic of Serbia, project III 46002 and TR 31062.

\section{Procena energetskog statusa krava na osnovu telesne kondicije i parametara metaboličkog profila}

\author{
R. Prodanović, Ž. Sladojević, D. Kirovski, I. Vujanac, V. Ivetić, B. Savić, B. \\ Kureljušić, M. Stevančević
}

\section{Rezime}

Cilj istraživanja bio je da se ukaže na značaj metaboličkog profila i telesne kondicije u oceni energetskog statusa visoko-mlečnih krava holštajn rase. Za ispitivanje su odabrane tri grupe po sedam krava. Uzorci krvi uzimani su u zasušenju (15 dana pre očekivanog teljenja), ranom puerperijumu (7 dana nakon teljenja) i 60. dana laktacije. U uzorcima sveže krvi određivana je koncentracija glukoze i beta hidroksi-buterne kiseline (BHBA), a u uzorcima krvnog seruma koncentracija ukupnih proteina, ureje i ukupnog bilirubina. Rezultati ocene telesne kondicije pokazuju da su krave u periodu zasušenja preuhranjene $(X=4,03 \pm 0,29$ 
poena), dok su u puerperijumu ( $\mathrm{X}=2,85 \pm 0,46$ poena) i 60 . dana laktacije $(X=3,12 \pm 0,33$ poena) u značajno slabijoj telesnoj kondiciji $(p<0,001$ u odnosu na zasušenje). Rezultati ispitivanja parametara metaboličkog profila ukazuju da je koncentracija proteina jedino u periodu ranog puerperijuma bila niža od fiziološke vrednosti $(X=56,87 \pm 3,29 \mathrm{~g} / 1)$. Koncentracija glukoze nije se statistički značajno menjala tokom ispitivanih perioda, dok je neposredno posle teljenja došlo do značajnog povećanja koncentracije BHBA ( $<<0,001$ u odnosu na zasušenje). Uremija $\mathrm{u}$ periodu zasušenja $(X=7,73 \pm 2,34 \mathrm{mmol} / \mathrm{l})$, ranom puerperijumu $(X=8,07 \pm 3,09 \mathrm{mmol} / \mathrm{l})$ i 60 . dana laktacije $(X=7,41 \pm 2,03 \mathrm{mmol} / \mathrm{l})$ bila je veća od gornje fiziološke granice. Koncentracija ukupnog bilirubina u periodu zasušenja je bila značajno niža $(p<0,001)$ u odnosu na oba ispitivana perioda nakon teljenja. Na osnovu dobijenih rezultata može se zaključiti da krave nisu adekvatno pripremljene za nastupajuću laktaciju, zbog čega je kod njih došlo do značajnog odstupanja u telesnoj kondiciji i vrednostima parametara metaboličkog profila. Ova odstupanja ukazuju na nedovoljnu sposobnost životinja da se prilagode u uslovima negativnog bilansa energije na početku laktacije.

\section{References}

GUSTAFSSON A.H., ANDERSSONAP L., EMANUELSON U. (1995): Influence of feeding menagement, concentrate intake and energy intake on the risk of hyperketonaemia in Swedish dairy herds. Prev. Vet. Med., 22, 237-248.

HAYIRLI A., GRUMMER R.R., NORDHEIM E.V., CRUMP P.M. (2002): Animal and dietary factors affecting feed intake during the pre-fresh transition period in Holsteins. J. Dairy Sci., 85, 3430-3443.

IVANOV I., ŠAMANC H., VUJANAC I., DIMITRIJEVIĆ B. (2005): Metabolički profil krava. Zbornik radova IV simpozijuma:'Ishrana, reprodukcija i zaštita zdravlja goveda", Subotica.

JAZBEC I. (1990): Kliničko laboratorijska diagnostika. Veterinarski fakultet, Ljubljana.

KANEKO J.J. (1989): Clinical biochemisty of domestic animals, $4^{\text {th }}$ edition, San Diego.

KIDA K. (2003): Relationships of metabolic profiles to milk production and feeding in dairy cows. J. Vet. Med. Sci., 65, 6, 671-677.

KIROVSKI D., VUJANAC I., ŠAMANC H., FRATRIĆ N., GVOZDIČ D, SLADOJEVIĆ Ž, HRISTOV S. (2009): Metabolic profiles and health status of dairy cows kept under free and tie stall systems. Second proceeding of International Symposium „New Research in Biotecnology“, USAMV Bucharest, Romania, 181-186. 
LOTHHAMMER K.H. (1991): Uticaj i posledice neizbalansirane ishrane na zdravlje i plodnost mlečnih krava. Zbornik predavanja XX seminara za inovaciju znanja veterinara, Beograd, 71-102.

MARENJAK T.S., POLJIČAK-MILAS N., STOJEVIĆ Z. (2004): Svrha određivanja koncentracije ureje u kravljem mlijeku. Praxis veterinaria, 52, 3, 233-241. MILOVANOVIĆ A., JOVIČIN M., ŠAMANC H. (2005): Ocenjivanje telesne kondicije krava holštajn-frizijske rase. Veterinarska komora Srbije, Beograd. MORROW D.A. (1976): Fat cow syndrome. J. Dairy Sci., 59, 1625-1629.

PRODANOVIĆ R., KIROVSKI D., JAKIĆ-DIMIĆ D., VUJANAC I., KURELJUŠIĆ B. (2010): Telesna kondicija i pokazatelji energetskog statusa krava u visokom graviditetu i ranoj fazi laktacije. Vet. Glasnik, 63, 1-2, 43-52.

REIST M., ERDIN D., von EUV D., TSCHUEMPERLIN K., LEUENBERGER H., CHILLIARD Y., HAMMON H.M., MOREL C., PHILIPONA C., ZBINDEN Y., KUENZI N., BLUM J.W. (2002): Estimation of energy balance at individual and herd level using blood and milk traits in high-yielding dairy cows. J. Dairy Sci., 85, 3314-3327.

ROSENBERGER G. (1995): Clinical Examination of Cattle, Blackwell Science Ltd.

RUKKWAMSUK T., KRUIP T.A., WENSING T. (1999): Relationship between overfeeding and over-conditioning in the dry period and the problems of high producing dairy cows during the post-parturient period, Vet. Q., 21, 71-77.

STEGARDE L., TRAVEN M., EMANUELSON U., HOLTENIUS K., HULTGREN J., NISKANEN R. (2008): Metabolic profiles in five high-producing Swedish dairy herds with a history of abomasal displacement and ketosis. Acta Vet. Scand., 50, 31.

ŠAMANC H., JOVANOVIĆ M., DAMNJANOVIĆ Z., IVANOV I. (1992): Koncentracija amino-kiselinskog azota i ukupnog bilirubina u krvnom serumu visokogravidnih i tek oteljenih junica istočno-frizijske i holštajn rase. Vet. Glasnik, 46, 7-8, 377-381.

ŠAMANC H., KIROVSKI D., JOVANOVIĆ M., VUJANAC I., BOJKOVIĆKOVAČEVIĆ S., JAKIĆ-DIMIĆ D., PRODANOVIĆ R., STAJKOVIĆ S. (2010): New insights into body condition score and its association with fatty liver in Holstein dairy cows. Acta veterinaria, 60, 5-6, 525-540.

ŠAMANC H., STOJIĆ V., KIROVSKI D., JOVANOVIĆ M., CERNESCU H., VUJANAC I., PRODANOVIĆ R. (2008): Uticaj telesne kondicije krava na učestalost i stepen zamašćenja jetre. Vet. Glasnik, 62, 1-2, 1-130. 